\title{
COMPARISON OF THE CAFFEINE SKINNED FIBRE TENSION (CSFT) TEST WITH THE CAFFEINE-HALOTHANE CONTRACTURE (CHC) TEST IN THE DIAGNOSIS OF MALIGNANT HYPERTHERMIA
}

\author{
Beverley A. Britt, Wanda Frodis, Elizabeth Scott, Mary-Jean Clements \\ AND LASZLO ENDRENYI
}

\begin{abstract}
We have compared and contrasted two diagnostic tests for Malignant Hyperthermia (MH) the Caffeine-Halothane Contracture Test and the Caffeine Skinned Fibre Tension Test. Both tcsts show a strongly positive relationship both with the occurrence of MH reactions and with each other. The former test is more rapid and requires less skill. The latter test can be performed on much less muscle and permits storage of the muscle over prolonged periods of time.
\end{abstract}

KEY WORDS: HYPERTHERMIA, malignant, caffeine-halothane contracture test, caffeine skinned fibre tension test.

DEvelopMENT OF THE caffeine-halothane contracture (CHC) test in $1968^{\prime}$ made reasonably accurate diagnosis of maligant hyperthermia (MH) possible for the first time. This test, now considerably refined, is done today in many laboratories throughout the world. ${ }^{2-21}$ However the $\mathrm{CHC}$ test has the disadvantages of requiring not only a large volume of muscle but also fresh muscle with, therefore, little or no possibility of rectifying experimental errors. Moreover, while the CHC test indicates that an error of calcium distribution in the muscle cell precipitates $\mathrm{MH}$ reactions, it does not pin-point the site of the defect.

In 1975 Wood, et al. ${ }^{22}$ described a rapid and simplified method for preparing single chemically skinned skeletal muscle fibres. In these fibres, consisting only of sarcoplasmic reticulum (SR) and myofibrils, it was possible to determine release of calcium from the $S R$ and contractile effect of calcium on the myofibrils. The volume

Beverley A. Britt, M.D., F.R.C.P.(C), Associate Professor, Departments of Anaesthesia and Pharmacology; Wanda Frodis, B.Sc.; Elizabeth Scott, M.Sc. Laboratory Technicians, Department of Anaesthesia Mary-Jean Clements, B.Sc., Computer Programmer, Department of Pharmacology; Laszlo Endrenyi, Ph.D., Professor, Departments of Preventative Medicine and Biostatistics, and Pharmacology; University of Toronto, Toronto, Canada.

For Reprints: Dr. B.A. Britt, Department of Pharmacology, Medical Sciences Building, University of Toronto, Toronto, Ontario, Canada, M5S IA8. of muscle required was small. Moreover, fibres prepared from muscle stored for several months in the freezer were still viable. We felt, therefore, that a diagnostic test for MH based on this preparation might have several advantages over the $\mathrm{CHC}$ test of intact muscle fascicles. Much less muscle would be needed. Experimental errors could be rectified by another trip to the freezer. Considerable information might be learned about the site and nature of the $\mathrm{MH}$ defect.

In 1977, therefore, during the course of routine biopsies in suspected $\mathrm{MH}$ patients, in addition to obtaining muscle for our usual diagnostic tests (CHC test, ${ }^{2,3}$ halothane-ATP depletion test (H-ATP-D), ${ }^{3}$ and routine microscopy ${ }^{2}$, we also excised small strips of muscle secured to wooden sticks. These were chemically skinned by the method of Wood ${ }^{22-25}$ and were then sent to him by private courier for examination. Wood found that in malignant hyperthermic susceptible (MHS) muscle a larger than normal percentage of fibres developed tensions at lower than normal caffeine concentrations. ${ }^{25}$ Because of these promising preliminary findings we decided to examine in detail in our own laboratory the value of this technique as a sole diagnostic test, as a complement to the $\mathrm{CHC}$ test and as an aid in learning more about the nature of the MH defect. The test has now been named the caffeine skinned fibre tension (CSFT) test.

Can. Anaesth. Soc. J., vol. 29, no. 6, November 1982 
Methods

\section{A Anaesthetic Techniques}

Each patient was premedicated with diazepam $0.25 \mathrm{mg} \cdot \mathrm{kg}^{-1}$ and pantopon $0.25 \mathrm{mg} \cdot \mathrm{kg}^{-1}$. Anaesthesia was induced with nitrous oxide: oxygen 6L:4L per minute for two minutes followed by Innovar ${ }^{\otimes} 0.05 \mathrm{ml} \cdot \mathrm{kg}^{-1}$ and then a sleep dose of diazepam. The vocal cords were sprayed with cocaine 5.0 per cent and intubation was with floppy cuffed plastic tracheal tubes. Because of lack of good relaxation of the vocal cords the tubes selected were one size smaller than would usually have been employed. Anaesthesia was maintained with nitrous oxide:oxygen 6L:4L per minute through a semiclosed circle system incorporating a soda lime cannister. The gas machine contained no vaporizors. The soda lime cannister and all rubber tubing on the gas machine was vapour free. Each patient was hyperventilated with an Air Shields ventilator. If necessary the anaesthetic was supplemented with fentanyl. At the end of the biopsy the anaesthetic was reversed with naloxone 0.005 $\mathrm{mg} \cdot \mathrm{kg}^{-1}$. Before, during and after anaesthesia hydration was maintained with intravenous lactated Ringer's solution in five per cent glucose. Monitoring included electrocardiogram; blood pressure; heart rate; axillary, nose and rectal temperatures; skin colour, moisture, and circulation; skeletal muscle tone; blood gases and serum electrolytes and enzymes.

\section{B Caffeine-Halothane Contracture (CHC) Test on Intact Muscle Fascicles}

\section{Excision of Muscle Samples}

The surface of the quadriceps muscle was exposed by standard surgical techniques. Before excision of the muscle the ends of each six $\mathrm{cm}$ long by two $\mathrm{cm}$ thick sample were secured with black silk sutures. Each specimen was then meticulously dissected free from the surrounding main muscle belly with blunt dissection, while maintaining constant but gentle tension on the sutures in such a manner as to preserve each sample free from contractures or stretching. Care was taken to make the long cuts parallel to the long sides of the muscle cells.

Each muscle sample was placed immediately in a thermos of Krebs Ringer solution (Table I) at $\mathrm{pH} 7.4$ and $22^{\circ} \mathrm{C}$. The specimens were transported to the laboratory as quickly as possible. The time elapsed between excision and further processing was between ten and thirty minutes.
TABLE 1

Human Krebs Ringer's SOlution

\begin{tabular}{c}
$118.4 \mathrm{mM} \mathrm{NaCl}$ \\
$3.4 \mathrm{mM} \mathrm{KCl}$ \\
$0.8 \mathrm{mM} \mathrm{MgSO}$ \\
$1.2 \mathrm{mM} \mathrm{KH} \mathrm{PO}_{4}$ \\
$11.1 \mathrm{mM} \mathrm{Glucose}$ \\
$24.9 \mathrm{mM} \mathrm{NaHCO}$ \\
$2.5 \mathrm{mM} \mathrm{CaCl}_{2}$ \\
\hline
\end{tabular}

$\mathrm{pH}=7.4$

The specimens were trimmed free of any irregularities, fat or connective tissue.

\section{Preparation and Mounting of Muscle Fasci- cles (Figure 1)}

Each muscle sample was subdivided into smaller fascicles of approximately one to 1 wo $\mathrm{cm}$ by $0.1-0.3 \mathrm{~cm}$, and weighing about 100 to 300 $\mathrm{mg}$.

The lower end of each fascicle was secured by a $5^{\circ}$ black silk suture to a plastic electrode frame (Figure 1) and immersed in $40 \mathrm{ml}$ of Krebs Ringer solution at $\mathrm{pH} 7.4$ and at $37^{\circ} \mathrm{C}$. The bathing solutions were bubbled with 95 per cent oxygen and 5 per cent carbon dioxide. This gas mixture at the rate of $20 \mathrm{ml}$ per minute entered the bottom of the bathing chamber through scintered porous discs. The discs broke the gas into very small bubbles, thus increasing the area of surface contact between gas and muscle. The upper end of each muscle was connected by a second $5^{\circ}$ black silk suture to a model FT.03 Grass force displacement transducer (Figure 1). Isometric tension was recorded with a Grass model 7 polygraph. The initial tension was set at 2.0 grams. Each fascicle was stimulated for four milliseconds once every five seconds through a

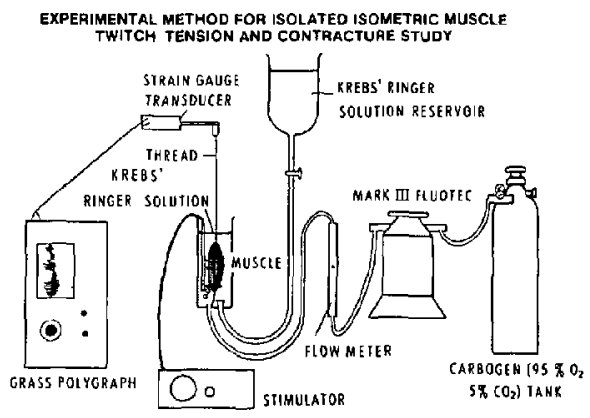

FIGURE 1 Schematic drawing of experimental method for study of isolated isometric muscle twitch tension and contracture. 
platinum electrode. These electrodes were supported by the plastic frames; their tips projecting out from the frames touched the mid point of each fascicle. The electrodes were connected individually to constant voltage custom built rectangular pulse stimulators. The voltage applied to each fascicle was that which induced a twitch tension slightly less than supramaximal. To prevent dissipation of the electrical current each electrode was coated with liquid plexiglass except for the area in contact with the muscle fascicles.

\section{Determination of MHS Status by Measure} ment of Caffeine, Halothane and Caffeine Plus Halothane Induced Contractures of Intact Muscle Fascicles

Caffeine, an agent known to inhibit calcium uptake into the $\mathrm{SR}^{26-30}$ was added directly to each of two duplicate baths in increments from 1.0 to $32.0 \mathrm{mM}$. Each caffeine dose was left in the bath for five minutes. For every dose the maximum contracture (increase in resting tension) amplitude achieved within the first fou minutes was measured. The caffeine was then removed and replaced by a dose double that of the previous concentration.

From the mean of the log caffeine-contracture curves, the concentration of caffeine in $\mathrm{mM}$ required to raise the resting tension of the fascicles by one gram, was calculated. The value was defined as the "caffeine specific concentration" (CSC).

Separate duplicate fascicles were equilibrated for fifteen minutes with 1.0 volume per cent halothane added from a Mark 3 Fluotec ${ }^{2}$ vaporizer through the carbogen line. Caffeine was then added as before, but in increments ascending from $0.25 \mathrm{mM}$. A smaller starting dose was used because of the potentiating effect of halothane on the caffeine induced contractures. The gram tension increase for 1.0 volume per cent halothane alone (H-Cont) and then for each dose of caffeine plus 1.0 volume per cent halothane was measured as previously. From the resulting log caffeine plus halothane-contracture curves the caffeine specific concentration without halothane (CSC-H) was calculated

\section{Caffeine Skinned Fibre Tension (CSFT) Test \\ 1 Excision of Muscle Fascicle}

By the method of Wood ${ }^{22,25}$ balsa sticks two cm long were prepared with grooves close to each end. Each stick was then placed over a small quadriceps fascicle of a similar length. The ends of the fascicle were then secured by means of $5^{\circ}$ black silk sutures to the grooves in such a fashion as to ensure that the fascicle was held to neutral length. The belly of the fascicle was freed from the main quadriceps muscle by blunt dissection. Finally the ends of the fascicle were freed by sharp dissection. Great care was taken to ensure that the volume of dissection included only that muscle lying between the sutures (Figure 2).

\section{Skinning of Muscle Cells}

The muscle fascicles on their sticks were placed immediately in a relaxing solution (Table II, Figure 2). Within the first hour each fascicle was transferred at least three times to fresh relaxing solution following which the fascicles in their relaxing solution were kept in a refrigerator at $4^{\circ} \mathrm{C}$ for 24 hours. They were then transferred to a skinning-storage solution which was identical in all ways to the relaxing solution except for the addition of 50 per cent glycerol. Over a period of several days at $-20^{\circ} \mathrm{C}$ this solution skinned off (functionally destroyed) the sarcolemma and mitochondria chemically and disrupted the gap junctions (excitation-contraction coupling steps) between the transverse tubules and the sarcoplasmic reticulum. The final preparation, therefore, ready for use after four to ten days, consisted of only sarcoplasmic reticulum plus myofibrils.

\section{Mounting of Single Skinned Fibres}

When skinning was functionally complete, single cells were dissected from the main fascicle (Figure 3) under a 40 power Swift Model 31-400-00 binocular microscope. Each was then mounted horizontally between two clamps in a

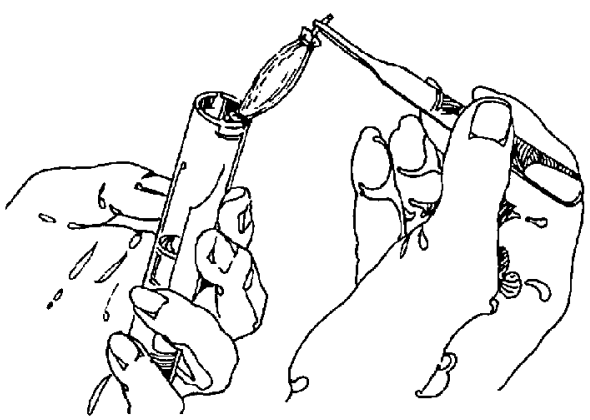

FIGURE 2 Preparation for study of chemically skinned muscle cells. The excised muscle fascicle is secured to a balsa stick two $\mathrm{cm}$ long and placed immediately in a relaxing solution. 
TABLE II

REIAXING SOLUTION

$$
\begin{aligned}
& 170,0 \mathrm{mM} \text { K Propionate } \\
& 5.0 \mathrm{mM} \text { EGTA } \\
& 10.0 \mathrm{mM} \text { Imidazole } \\
& 2.5 \mathrm{mM} \text { Mg Propionate } \\
& 2.5 \mathrm{mM} \text { ATP } \\
& \text { pH }=7.0 .
\end{aligned}
$$

bathing chamber (Figure 4) filled with a calcium free relaxing solution (Table II). One of these clamps was attached to a micromanipulator and the other to a Grass Model FT.03C force transducer. The mounted skinned fibres were each viewed through a 400 power Olympus Model KCP-TR-2 inverted microscope (Figure $5)$. Changes in tension were recorded on a Gould-Brush Model 2200 square wave polygraph.

For every patient at least five fibres, an average of six, and a maximum of 23 fibres were assessed. The mean values of all fibres from each patient were calculated.

4 Determination of Caffeine-Induced Tension Increase (Calcium Release from the Sarcoplasmic Reticulum) of Single Chemically Skinned Fibres

$\mathrm{Ca}^{++}=\mathrm{pCa} 6.8$ was added to the relaxing solution bathing each skinned muscle cell. After 30 seconds the sarcoplasmic reticulum having been loaded with calcium, the solution was removed from the chamber and replaced with a

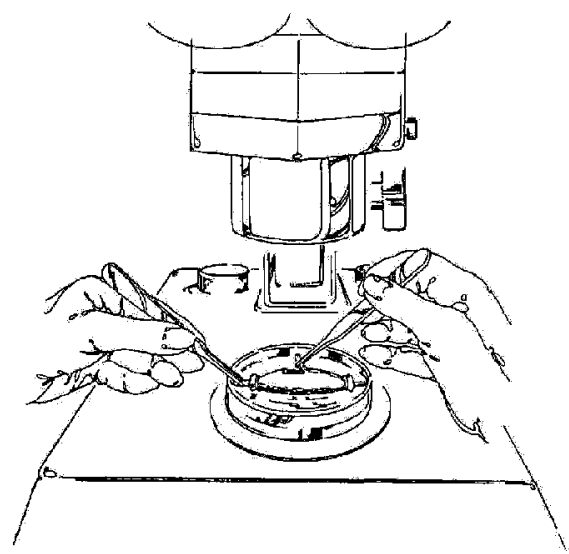

FIGURE 3 Preparation for study of chemically skinned muscle cells. When skinning is functionally complete single cells are dissected from the main fascicle under a 40 power microscope.

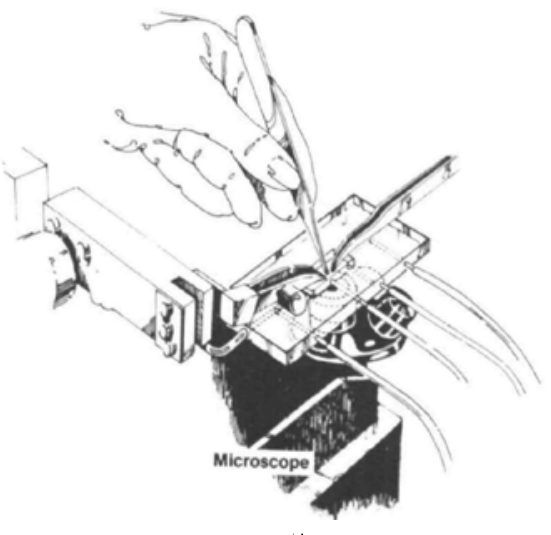

Figure 4 Study of chemically skinned muscle cells. Each cell is mounted horizontally between two clamps in a bathing chamber filled with a calcium free relaxing solution.

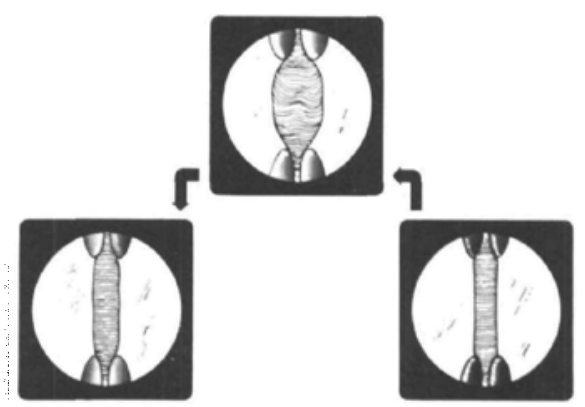

Figure 5 Study of chemically skinned muscle cells. Drawing shows changes in contraction of a muscle cell as viewed through a 400 power inverted microscope.

contracting solution which contained caffeine but no ionized calcium (Table III). The ensuing increase in tension of each muscle cell was due to release of calcium from the preloaded (since the exogenous solution bathing the sarcoplasmic reticulum-myofibrillar complex was calcium free). The procedure was repeated several times using progressively larger concentrations of caffeine so that dose-response curves were obtained. Between every set of calcium and caffeine additions each fibre was thoroughly rinsed at least twice with a washing solution (Table IV). Then any calcium still remaining in the sarcoplasmic reticulum was removed by adding caffeine $40 \mathrm{mM}$ followed by further application of relaxing (Table II) and washing (Table IV) solutions. From the caffeine-tension curves the dose of caffeine required to initiate tension rise 
TABLE III

Contracting SOLUTION

$185.0 \mathrm{mM}$ K Propionate

$10.0 \mathrm{mM}$ Imidazole

$2.5 \mathrm{mM} \mathrm{Mg}$ Propionate

$40.0 \mathrm{mM}$ Caffeine*

$2.5 \mathrm{mM}$ ATP

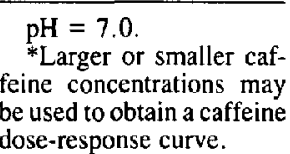

TABLE IV

WASHING Solution

$185.0 \mathrm{mM} \mathrm{K}$ Propionate

$10.0 \mathrm{mM}$ Imidazole

$2.5 \mathrm{mM} \mathrm{Mg}$ Propionate

$2.5 \mathrm{mM}$ ATP

$\mathrm{pH}=7.0$.

(Sk-Caff-D) and the maximum tension amplitude in $\mathrm{kg} / \mathrm{cm}^{2}$ (Sk-Caff-Max) was calculated. Finally, from the calcium-tension curves the dose of calcium required to initiate tension rise (Sk-Ca-D) was calculated.

\section{Determination of Calcium Induced Tension Increase of Single Chemically Skinned} Fibres

The bathing chamber was filled with a relaxing solution (Table II) which induced movement of free calcium out of the sarcoplasmic reticulum, thus depleting it of calcium. Then after several applications of washing solution (Table IV) the bathing chamber was filled with a solution which contained no caffeine but which did contain ionized calcium (Table $V$ ). This procedure was repeated several times using incremental concentrations of calcium so that a calcium-tension curve was obtained. Tension increases were considered to be due to the direct effect of the exogenous calcium since no calcium was available in the sarcoplasmic reticulum for release. From the dose-response (calciumtension) curves the mean threshold dose of calcium required to initiate tension rise (Sk-CaD) was calculated.

6 Determination of Adequacy of Skinning and Viability of Sarcoplasmic Reticulum

Evidence for the fibres being functionally skinned and viable for the study of $\mathrm{Ca}^{++}$uptake and release from the sarcoplasmic reticulum came from the following observations:

(i) electron micrographs of the fibres showed the sarcolemma to be disrupted, the transverse tubules to be separated from the sarcoplasmic reticulum, the mitochondria to be absent or abnormal and the myofibrils and the sarcoplasmic reticulum to be intact;

(ii) after addition of caffeine to fibres preloaded with subcontractile doses of calcium or after addition of contractile doses of calcium to fibres predepleted of calcium, tensions after initial rises always returned to zero. This showed that the sarcoplasmic reticulum was able to take up enough free calcium from the myoplasm to allow complete relaxation to occur;

(iii) both with and without calcium the fibres developed rigor tension in the absence of ATP and relaxation returned only with the restoration of ATP;

(iv) at the end of examination of each fibre the dose of calcium which had been initially determined to induce maximum tension was reapplied. Values obtained on fibres where maximum tension at the end of each experiment was less than 80 per cent of the maximum tension at the beginning of the experiment were excluded from statistical analysis of the calcium-tension curves.

\section{Classification of Patients}

MHS Individuals comprised persons whose CSC-H was less than $1.0 \mathrm{mM}$. They had either had MH reactions (MHS Patients) or were relatives of those who had had such reactions (MHS Relatives).

Normal Individuals comprised persons whose $\mathrm{CSC}-\mathrm{H}$ was more than $1.0 \mathrm{mM}$. None had had a MH reaction. Some were relatives of MHS patients (Normal Relatives) while others were not (Control Patients).

First, and $\geqslant$ Second Degree Relatives. MHS Relatives and Normal Relatives were subdivided into First Degree $\left(1^{\circ}\right)$ Relatives and $\geqslant$ Second Degree $\left(2+{ }^{\circ}\right)$ Relatives. $1^{\circ}$ relatives included siblings, parents and offspring. $2+{ }^{\circ}$ relatives included aunts and uncles, nieces and nephews and grandparents and grandchildren and all individuals still more distantly related to MHS patients.

In the above classifications the presence or absence of a previous $\mathrm{MH}$ reaction was always a dependent variable. CSC-H above or CSC-H below $1.0 \mathrm{mM}$ was an independent variable with respect to absence or presence of a previous $\mathrm{MH}$ 
TABLE $V$

Calcium Solutions

\begin{tabular}{ccccccc}
\hline \hline pCa & Ca EGTA & EGTA & Mg & K & Imid. & ATP \\
\hline 6.8 & $1.15 \mathrm{mM}$ & $3.85 \mathrm{mM}$ & $2.46 \mathrm{mM}$ & $172 \mathrm{mM}$ & $10 \mathrm{mM}$ & $2.5 \mathrm{mM}$ \\
6.4 & $2.10 \mathrm{mM}$ & $2.85 \mathrm{mM}$ & $2.44 \mathrm{mM}$ & $172 \mathrm{mM}$ & $10 \mathrm{mM}$ & $2.5 \mathrm{mM}$ \\
6.0 & $3.27 \mathrm{mM}$ & $1.73 \mathrm{mM}$ & $2.42 \mathrm{mM}$ & $172 \mathrm{mM}$ & $10 \mathrm{mM}$ & $2.5 \mathrm{mM}$ \\
5.6 & $4.14 \mathrm{mM}$ & $0.86 \mathrm{mM}$ & $2.40 \mathrm{mM}$ & $172 \mathrm{mM}$ & $10 \mathrm{mM}$ & $2.5 \mathrm{mM}$ \\
5.2 & $4.64 \mathrm{mM}$ & $0.36 \mathrm{mM}$ & $2.40 \mathrm{mM}$ & $172 \mathrm{mM}$ & $10 \mathrm{mM}$ & $2.5 \mathrm{mM}$ \\
5.0 & $4.78 \mathrm{mM}$ & $0.22 \mathrm{mM}$ & $2.40 \mathrm{mM}$ & $172 \mathrm{mM}$ & $10 \mathrm{mM}$ & $2.5 \mathrm{mM}$ \\
4.8 & $4.88 \mathrm{mM}$ & $0.11 \mathrm{mM}$ & $2.40 \mathrm{mM}$ & $172 \mathrm{mM}$ & $10 \mathrm{mM}$ & $2.5 \mathrm{mM}$ \\
\hline
\end{tabular}

$\mathrm{pH}=7.02$.

reaction but was a dependent variable with respect to all other parameters for reasons described in the following section.

In addition we also attempted to classify MHS and normal individuals into several quantitative categories on the basis of whether or not their muscle exhibited halothane induced contractures (H-Conts), lower than normal CSC or lower than normal Sk-Caff-D.

Thus on the basis of the CHC test values the muscle could be assigned rather readily to one of the following categories:

1 Type $\mathrm{HCK}^{*}$ were those whose fascicles developed contractures in the presence of halothane alone, had CSC of less than $4.0 \mathrm{mM}$; and had CSC-H of less than $1.0 \mathrm{mM}$;

2 Type CK were those whose fascicles did not exhibit $\mathrm{H}$-Conts but had CSC of less than 4.0 $\mathrm{mM}$; and had $\mathrm{CSC}-\mathrm{H}$ of less than $1.0 \mathrm{mM}$;

3 Type $\mathrm{K}$ were those whose fascicles did not exhibit $\mathrm{H}$-Conts and had CSC of more than 4.0 $\mathrm{mM}$; but did have $\mathrm{CSC}-\mathrm{H}$ of less than $1.0 \mathrm{mM}$;

4 Type $\mathrm{N}$ were those normal individuals whose fascicles did not develop H-Conts, had CSC of more than $4.0 \mathrm{mM}$ and $\mathrm{CSC}-\mathrm{H}$ of more than $1.0 \mathrm{mM}$.

\section{RESULTS}

MHS Patients versus Control Patients (Table VI) All MHS patients had CSC-H of less than 1.0 $\mathrm{mM}$ while all control patients had $\mathrm{CSC}-\mathrm{H}$ of more than $1.0 \mathrm{mM}$. Because of this clear-cut

*HCK: $\mathbf{H}=$ halothane; $\mathrm{C}=$ caffeine, $\mathrm{K}=$ halothane + caffeine. The letter " $K$ " has been chosen at Dr. T. Nelson's suggestion to honour Dr. Werner Kalow, an early pioneer in $\mathrm{MH}$ research and also because $\mathrm{H}$ (halothane), the eighth letter of the alphabet, plus C (caffeine), the third letter of the alphabet $=$ 11 , and $\mathrm{K}$ is the 11 th letter of the alphabet. distinction this parameter was used as the yardstick to assess the value of all other parameters measured.

CSC were significantly lower in MHS Patients than in control patients. In the former, CSC were usually less than $4.1 \mathrm{mM}$ while in the latter CSC were always more than $4.1 \mathrm{mM}$. Some of the MHS patients, however, had CSC of more than 4. I $\mathrm{mM}$ although the extremely high values not infrequently observed in control patients (maximum $15.0 \mathrm{mM}$ ) were never seen in MHS patients (maximum $6.4 \mathrm{mM}$ ).

Fascicles excised from control patients never developed contractures in the presence of halothane alone $(H$. Cont). Conversely a few (three) of the fascicles from the MHS patients did develop contractures in the presence of halothane alone. All the latter had CSC of less than $4.1 \mathrm{mM}$ and usually substantially less than $3.0 \mathrm{mM}$.

Sk-Caff-Max of the MHS patients' fibres were statistically similar to the Sk-Caff-Max of the control patients' fibres. The difference between the two groups, therefore, appeared to be due to the rate at which caffeine induced release of calcium from the sarcoplasmic reticulum and not to the total amount of calcium released from the sarcoplasmic reticulum.

Sk-Caff-D were significantly lower in MHS patients than in control patients. Thus, in MHS patients' fibres, a smaller concentration of caffeine was required to initiate calcium release and thence to induce a rise in tension of the myofibrils than in the fibres from control patients.

In skinned fibres which had been predepleted of calcium, the SK-Ca-D for the MHS patients did not differ significantly from the SK-Ca-D for the control patients. Thus the direct responsiveness of the myofibrils of MHS patients to exogenous calcium was similar to that of the myofibrils of control patients. 
TABLE VI

Caffeine-Halothane Contracture Test vs. Caffeine Skinned Fibre Tension Test for MHS vs. Control Patients

\begin{tabular}{|c|c|c|c|}
\hline $\begin{array}{l}\text { Skeletal Muscle } \\
\text { Biopsy Parameter }\end{array}$ & $\begin{array}{c}\text { MHS } \\
\text { Patients }\end{array}$ & $\begin{array}{l}\text { Control } \\
\text { Patients }\end{array}$ & $t(\mathrm{df})$ \\
\hline $\begin{array}{l}\text { Dependent } \\
\text { CSC-H }^{1}\end{array}$ & $\begin{array}{l}0.806 \S \\
0.949 \dagger \\
(16) \infty\end{array}$ & $\begin{array}{l}1.92 \S \\
1.17 \dagger \\
(10) \infty\end{array}$ & $\begin{array}{l}2.66^{*} \\
(24)\end{array}$ \\
\hline $\begin{array}{l}\text { Independent } \\
\mathrm{CSC}^{2}\end{array}$ & $\begin{array}{l}3.69 \\
1.30 \\
(16)\end{array}$ & $\begin{array}{l}7.53 \\
3.48 \\
(10)\end{array}$ & $\begin{array}{l}4.03 * * * \\
(24)\end{array}$ \\
\hline Sk-Ca-D $D^{3}$ & $\begin{array}{l}6.05 \\
0.166 \\
(13)\end{array}$ & $\begin{array}{l}5.96 \\
0.167 \\
(19)\end{array}$ & $\begin{array}{l}1.249^{n .5} \\
(20)\end{array}$ \\
\hline Sk-Caff-D ${ }^{4}$ & $\begin{array}{l}3.20 \\
2.03 \\
(16)\end{array}$ & $\begin{array}{l}5.72 \\
1.74 \\
(10)\end{array}$ & $\begin{array}{l}3.25 * * \\
(24)\end{array}$ \\
\hline Sk-Caff-Max ${ }^{5}$ & $\begin{array}{l}2.65 \\
0.79 \\
(15)\end{array}$ & $\begin{array}{l}2.62 \\
0.89 \\
(10)\end{array}$ & $\begin{array}{l}0.09^{n . s .} \\
(23)\end{array}$ \\
\hline
\end{tabular}

${ }^{1}$ Caffeine Specific Concentration with 1.0 volume per cent halothane

${ }^{2}$ Caffeine Specific Concentration

${ }^{3}$ Dose of $\mathrm{Ca}^{++}$required to induce directly a tension increase of myofibrils of single skinned fibres.

${ }^{4}$ Dose of Caffeine recuired to induce indirectly a tension increase of single skinned fibres by release of $\mathrm{Ca}^{++}$from the sarcoplasmic reticulum.

${ }^{5}$ Maximum amplitude of tension caused by caffeine induced calcium release from the sarcoplasmic reticulum of single skinned fibres

\$Mean.

tStandard Deviation.

$\infty$ Sample Size

$* * * p<0.001$

$*_{p}<<0.01$

$*_{p}<0.05$.

n.s. not significant.

MHS Individuals (MHS Patients Plus MHS Relatives) Versus Normal Individuals (Normal Relatives Plus Control Patients (Table VII)).

CSC was significantly lower in MHS than in normal fascicles. However, some overlapping between the two groups did occur. In the normal fascicles CSC was always at least $4.1 \mathrm{mM}$ and usually (in all except four fascicles) were greater than $5.0 \mathrm{mM}$. In the MHS fascicles CSC was usually less than $4.1 \mathrm{mM}$. In seven MHS fascicles, however, the CSC was between 4.2 and $4.9 \mathrm{mM}$ and in a further two MHS fascicles the CSC was between 5.2 and $6.4 \mathrm{mM}$.

None of the normal fascicles developed contractures in the presence of halothane alone. On
TABLE VII

Caffeine-Halothane Contracture Test vs Caffeine Skinned Fibre Tension Test for MHS vs. NORMAL INDIVIDUALS

\begin{tabular}{cccl}
\hline \hline $\begin{array}{c}\text { Skeletal Muscle } \\
\text { Biopsy Parameter }\end{array}$ & $\begin{array}{c}\text { MHS } \\
\text { Patients }\end{array}$ & $\begin{array}{c}\text { Control } \\
\text { Paticnts }\end{array}$ & \multicolumn{1}{c}{$t(\mathrm{df})$} \\
\hline Dependent & & & \\
CSC-H $^{1}$ & $0.49 \S$ & $2.31 \S$ & $9.21^{\text {*** }}$ \\
& $0.24 \dagger$ & $1.29 \dagger$ & $(92)$ \\
& $(44) \infty$ & $(50) \infty$ & \\
Independent & & & \\
CSC $^{2}$ & 3.32 & 6.15 & $6.39 * * *$ \\
& 1.69 & 2.47 & $(92)$ \\
& $(44)$ & $(50)$ & \\
Sk-Ca-D & 5.68 & 6.76 & $1.90^{\text {n.s. }}$ \\
& 1.93 & 3.30 & $(91)$ \\
& $(44)$ & $(49)$ & \\
Sk-Caff-D & 2.99 & 4.46 & $3.63^{* * * *}$ \\
& 2.03 & 1.90 & $(92)$ \\
& $(44)$ & $(50)$ & \\
Sk-Caff-Max & 2.49 & 2.50 & $0.073^{\text {n.s. }}$ \\
& 0.65 & 0.67 & $(91)$ \\
& $(44)$ & $(49)$ & \\
\hline
\end{tabular}

${ }^{\prime}$ Caffeine Specific Concentration with 1.0 volume per cent halothane.

${ }^{2}$ Caffeine Specific Concentration

${ }^{3}$ Dose of $\mathrm{Ca}^{++}$required to induce directly a tension increase of myofibrils of single skinned fibres.

${ }^{4}$ Dose of Caffeine required to induce indirectly a tension increase of single skinned fibres by release of $\mathrm{Ca}^{++}$from the sarcoplasmic reticulum.

${ }^{5}$ Maximum amplitude of tension caused by caffeine induced calcium release from the sarcoplasmic reticulum of single skinned fibres.

§Mean.

$\uparrow$ Standard deviation.

cSample size.

$* * * p<0.001$.

n.s. Not Significant.

the contrary, contractures occurred in five of the MHS fascicles in the presence of halothane alone (H-Cont).

Sk-Caff-D was significantly lower in MHS than in normal fibres. The smallest caffeine threshold for tension increase in normal fibres was $3.0 \mathrm{mM}$ while the highest was $10.2 \mathrm{mM}$. In the overwhelming majority of normal fibres the caffeine tension threshold was in excess of 4.5 $\mathrm{mM}$. The smallest Sk-Caff-D was $0.5 \mathrm{mM}$. In most MHS fibres the threshold was less than 4.5 $\mathrm{mM}$. There were, however, a very few outstanding exceptions. For example, one individual with muscle fascicles exhibiting a borderline CSC of $4.05 \mathrm{mM}$, a CSC-H of $0.52 \mathrm{mM}$ and no contractures in the presence of halothane alone exhibited onset of tension rise in skinned fibres at only $10.0 \mathrm{mM}$ of caffeine. The person from 
TABLE VIII A

Degree of Relationship to MHS Patients vs. Skeletal Muscle Biopsy RESULTS

\begin{tabular}{|c|c|c|c|c|}
\hline $\begin{array}{l}\text { Skeletal Muscle } \\
\text { Biopsy Parameter }\end{array}$ & $\begin{array}{c}\text { MHS } \\
\text { Patient }\end{array}$ & $1^{\circ}$ & $\begin{array}{c}2+{ }^{\circ} \\
\text { Relative }\end{array}$ & $\begin{array}{l}\text { Control } \\
\text { Patients }\end{array}$ \\
\hline $\mathrm{CHC}-\mathrm{H}^{1}$ & $\begin{array}{l}0.81 \S \\
0.95 \dagger \\
(16)^{\infty}\end{array}$ & $\begin{array}{l}1.65 \\
1.55 \\
(35)\end{array}$ & $\begin{array}{l}1.44 \\
1.18 \\
(33)\end{array}$ & $\begin{array}{l}1.92 \\
1.17 \\
(10)\end{array}$ \\
\hline $\mathrm{CHC}^{2}$ & $\begin{array}{l}3.69 \\
1.30 \\
(16)\end{array}$ & $\begin{array}{l}3.89 \\
2.28 \\
(35)\end{array}$ & $\begin{array}{l}5.55 \\
2.21 \\
(33)\end{array}$ & $\begin{array}{l}7.53 \\
3.48 \\
(10)\end{array}$ \\
\hline Sk-Ca-D ${ }^{3}$ & $\begin{array}{l}6.05 \\
0.17 \\
(13)\end{array}$ & $\begin{array}{l}5.92 \\
0.26 \\
(33)\end{array}$ & $\begin{array}{l}5.95 \\
0.22 \\
(28)\end{array}$ & $\begin{array}{c}5.96 \\
0.17 \\
(9)\end{array}$ \\
\hline Sk-Caff-D ${ }^{4}$ & $\begin{array}{l}3.20 \\
2.03 \\
(16)\end{array}$ & $\begin{array}{l}3.14 \\
1.61 \\
(35)\end{array}$ & $\begin{array}{l}4.28 \\
2.30 \\
(33)\end{array}$ & $\begin{array}{l}5.72 \\
1.74 \\
(10)\end{array}$ \\
\hline Sk-Caff-Max ${ }^{5}$ & $\begin{array}{l}2.65 \\
0.79 \\
(15)\end{array}$ & $\begin{array}{l}2.52 \\
0.60 \\
(35)\end{array}$ & $\begin{array}{l}2.37 \\
0.56 \\
(33)\end{array}$ & $\begin{array}{l}2.62 \\
0.89 \\
(10)\end{array}$ \\
\hline
\end{tabular}

${ }^{1}$ Caffeine Specific Concentration with 1.0 volume per cent halothane.

${ }^{2}$ Caffeine Specific Concentration.

${ }^{3}$ Dose of $\mathrm{Ca}^{++}$required to induce directly a tension increase of myofibrils of single skinned fibres.

${ }^{4}$ Dose of Caffeine required to induce indirectly a tension increase of single skinned fibres by release of $\mathrm{Ca}^{++}$from the sarcoplasmic reticulum.

${ }^{5}$ Maximum amplitude of tension caused by caffeine induced calcium release from the sarcoplasmic reticulum of single skinned fibres.

\$Mean.

† Standard Deviation.

$\infty$ Sample Size.

whom this muscle was obtained was only a sixth degree relative of a MHS patient and, therefore, highly unlikely to possess the MH trait. It would thus appear that in this individual, at least, the CSFT test gave a more reliable indication of her MH status than did the CHC test. Nevertheless, in a few other persons the reverse was true.

The Sk-Ca-D in fibres whose sarcoplasmic reticulum had been predepleted of calcium was statistically the same in the MHS as in the normal fibres.

Of the various parameters measured diagnostic discrimination between normal and MHS muscle was greatest for CSC and least for Sk-Caff-D.

Degree of Relationship to MHS Patients Versus Muscle Biopsy Values (Tables VIII A, VIII B)

Significantly positive correlations were observed between muscle biopsy parameters (CHC and $\mathrm{CHC}-\mathrm{H}$ of intact fascicles and Sk-Caff-D of skinned fibres) and closeness of relationship to MHS patients $\left(1^{\circ}\right.$ relatives, $2+^{\circ}$ relatives and control patients). Thus the more distant the relationship to the MHS patients the more closely the values resembled those of the control patients. On the other hand no positive correlations were found to exist between degree of relationship and $\mathrm{Gm}-\mathrm{H}$ of intact fascicles or Sk-Caff-Max or Sk-Ca-D of skinned fibres.

Pattern of Inheritance of CHC Test Abnormality and CSKT Abnormality

We were fortunate in being able to obtain multiple biopsies from each of several different families. For both the CHC test and the CSFT test, abnormal results showed distributions within the family which suggested: transmission through successive generations; direct transmission from affected fathers to sons and daughters; direct transmission from affected mothers to sons and daughters; and little or no sex influence in that the male to female ratio was not significantly different in those with abnormal biopsies from those with normal biopsies. Lower than normal Sk-Caff-D seemed to fit the pattern of a single autosomal dominant gene in that about 
TABLE VIII B

Correlation Coefficients From RegresSION ANalysis* fOR DEGREe of RELATION ShIP to MHS Patients vs. SKeletal Muscle BIOPSY RESULTS

\begin{tabular}{lr}
\hline \hline $\begin{array}{c}\text { Skeletal Muscle } \\
\text { Biopsy Parameter }\end{array}$ & $\begin{array}{c}\text { Correlation Coefficient } \\
(\mathrm{r})\end{array}$ \\
\hline CHC-H $^{1}$ & 0.783 \\
CHC $^{2}$ & 0.765 \\
Sk-Ca $^{++3}$ & -0.776 \\
Sk-Caff-T $^{4}$ & 0.805 \\
Sk-Caff-Max & -0.389 \\
\hline *Regression was performed on the points: \\
\hline X & Y \\
Relative & Mean Values Of: \\
\hline 0 & MHS Patients \\
1 & MHS Relative $1^{\circ}$ \\
2 & MHS Relative 2 + \\
3 & Control Patients \\
\hline
\end{tabular}

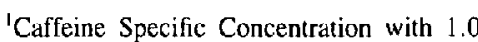
volume per cent halothane.

${ }^{2}$ Caffeine Specific Concentration.

${ }^{3}$ Dose of $\mathrm{Ca}^{++}$required to induce directly a tension increase of myofibrils of single skinned fibres.

${ }^{4}$ Dose of Caffeine required to induce indirectly a tension increase of single skinned fibres by release of $\mathrm{Ca}^{++}$from the sarcoplasmic reticulum.

${ }^{5}$ Maximal amplitude of tension caused by caffeine induced calcium release from the sarcoplasmic reticulum of single skinned fibres.

half the offspring of an affected parent manifested this hypersensitivity of their skinned fibres to caffeine and that the offspring's values tended to fall into one or other parental type. On the other hand lower than normal CSC and CSC-H of intact fascicles appeared to fit the hypothesis of two more autosomal genes in that often more than half the offspring of an affected parent exhibited hypersensitivity of their intact fascicles to caffeine (or caffeine plus halothane) and the offsprings' values usually were approximately the mean of those of the parents.

\section{Discussion}

The Sk-Caff-D part of the caffeine skinned fibre tension (CSFT) test provides more information about the primary defect of the $\mathrm{MH}$ trait than does the caffeine-halothane contracture ( $\mathrm{CHC}$ ) test. From the latter we have learned only that in MHS muscle the triggering agents caffeine and halothane induce excessive contractures. From the former we have learned in addition that in
MHS muscle the myofibrils are normal with respect to the contractile effects of calcium and that the triggering agent caffeine directly induces excessive release of calcium from the sarcoplasmic reticulum. It is this greater than normal extrusion of $\mathrm{Ca}^{++}$from the sarcoplasmic reticulum that causes actomyosin formation to begin in MHS fibres at lower caffeine concentrations than in normal fibres. The defect in the sarcoplasmic reticulum which makes them hypersusceptible to calcium efflux in the presence of caffeine has not been ascertained by the present study.

The CHC values imply but do not prove a defect in calcium uptake into the sarcoplasmic reticulum. The CSFT results do not confirm or rule out this possibility. The excessive contractures seen in MHS muscle in the presence of caffeine and/or halothane could be due to a defect in the sarcoplasmic reticulum which prevents reuptake into or binding by it. Alternatively, there may be sufficiently high levels of calcium in the myoplasm at the end of contraction that reduction below the contraction threshold $\left(5 \times 10^{-7} \mathrm{M}\right.$ of calcium) is impossible even for normal sarcoplasmic reticulum. The greater than normal release of calcium from the MHS sarcoplasmic reticulum in the presence of caffeine seen in the skinned fibres suggests the latter possibility. Further work is needed to clarify these various postulates. Although the skinned fibre data have demonstrated a primary defect in the sarcoplasmic reticulum of MHS muscle, it does not rule out concomitant primary defects in other muscle membranes. Thus it might be that similar calcium abnormalities also exist in one or more of the gap junctions between the transverse tubules and the sarcoplasmic reticulum, the transverse tubules, the sarcolemma, or the mitochondria. Additionally, myoplasmic proteins such as calmodulin ${ }^{33-35}$ or parvalbumin ${ }^{36}$ might also be less well able than normal to bind calcium.

Calcium induced calcium release from the sarcoplasmic reticulum is not thought to influence significantly myofibrillar tension induced by exogenous calcium stimulation. Normally, during an action. potential, "trigger" or "regenerative" subcontractile concentrations of calcium are released from the sarcolemma or transverse tubules. This "trigger" calcium then by an uncertain mechanism induces the release of still more calcium from the sarcoplasmic reticulum. ${ }^{31,37-40}$ Calcium induced calcium release from the sarcoplasmic reticulum appears to 
be independent of "depolarization" induced calcium release from the sarcoplasmic reticulum. ${ }^{40}$ Since sarcolemma and transverse tubules are not functional in our skinned fibres these membranes cannot serve as sources for "regenerative" calcium. However, Endo, et al. ${ }^{31}$ and Thorens, et $\mathrm{al}^{40}$ have reported that calcium induced calcium release from the sarcoplasmic reticulum can occur in skinned fibres devoid of functional sarcolemma and transverse tubules. They believe, in fact, that caffeine induced calcium release from the sarcoplasmic reticulum is secondary to acceleration of calcium induced calcium release. ${ }^{40}$ Recently Nelson, in still unpublished work has shown that exogenous calcium induced the release of much more calcium from isolated MHS sarcoplasmic reticulum than from the normal. ${ }^{41}$ In both Endo's and Nelson's studies, however, calcium induced calcium release occurs only when the sarcoplasmic reticulum of the fibres has been preloaded with calcium. In our fibres the sarcoplasmic reticulum has been predepleted of calcium. Therefore none has been available for release during the period of our experiment. Some of the exogenous calcium might have entered the sarcoplasmic reticulum at the same time as it was causing the myofibrils to contract and then might have been available for later induction of release by myoplasmic calcium acting as "trigger" calcium. These multiple steps would, of course, have taken much longer to complete than the single reaction of direct initiation of a rise in tension of the myofibrils by calcium.

In addition we believe, therefore, that in our fibres calcium induced calcium release cannot be the sole reason for the tension rises observed after the addition of caffeine, since all free calcium has been previously removed from the myoplasm and none has, consequently, been available to induce calcium release from the sarcoplasmic reticulum.

Our results for calcium related functions of single skinned fibres in normal and MHS patients are in substantial agreement with and complement those of Wood, ${ }^{23}$ Takagi, ${ }^{42} \mathrm{Na}-$ kano $^{43}$ and Hahn. ${ }^{44}$ Thus Wood has found that a higher than normal percentage of chemically skinned fibres had lower than normal caffeine thresholds for tension increase of single chemically skinned fibres. ${ }^{23}$ Takagi ${ }^{42,45}$ and Nakano ${ }^{43,46}$ have reported that halothane equilibration induces greater than normal tension increases in single skinned fibres isolated from MHS muscle. In addition Takagi ${ }^{47}$ has also found that the caffeine threshold for contracture is lower in MHS than in control single skinned fibres. $\mathrm{Hahn}^{44}$ has observed that caffeine causes a greater release of calcium from the sarcoplasmic reticulum of MHS than from that of normal fibres skinned by the mechanical method. Although the parameters measured and the techniques employed differ moderately in each of these studies, in combination they provide strong evidence that calcium release from the sarcoplasmic reticulum of MHS muscle is greater than normal in the presence of triggering substances such as caffeine or halothane.

Comparisons among the six parameters measured (H-Cont, CSC and CSC-H of intact fascicles, Sk-Caff-D, Sk-Caff-Max and Sk-Ca-D of single skinned fibres) show significantly positive correlations among all except Sk-Caff-Max and Sk-Ca-D. This was true both in studying the differences between muscle from MHS individuals and normal individuals, in examining the differences between muscle from MHS patients and muscle from control patients and, finally, in assessing the correlation coefficients between these parameters and the closeness of relationship to the MHS patients.

The CSC test yields the greatest statistical discrimination between MHS and normal muscle. However, the least amount of overlapping of values between MHS and normal patients is given by the CSC-H of intact fascicles. The latter test, therefore, provides the greatest reliability in diagnosing $\mathrm{MH}$ in individual cases. On the other hand, reliability of any one of H-Cont, CSC, or Sk-Caff-D would have led to a number of MHS patients who had had typical MH reactions and lower than normal CSC-H being wrongly classified as normal. In assessing individuals suspected of having $\mathrm{MH}$ these several tests must be used, therefore, in combination, just as one never places reliance on any single liver function test in diagnosing liver damage but rather performs an entire "battery" of liver function tests.

A few patients with no anaesthetic history of $\mathrm{MH}$ but with a history of severe muscle cramps and marked joint hypermobility were not included in this study. These individuals had normal CHC tests but abnormal Sk-Caff-D tests, i.e. lower than normal caffeine thresholds for tension increase of single skinned fibres. They probably had a disease different from but closely related to $\mathrm{MH}$. Because of this and because of the possibility of still other as yet undiagnosed calcium related muscle abnormalities, we feel that it is wise to continue testing as many 
parameters of calcium function in each muscle sample as possible.

The CSFT test (Sk-Caff-D) is of more recent origin than is the CHC test. ${ }^{1-18,20,21,48}$ It has not yet withstood the test of time and large sample sizes that the $\mathrm{CHC}$ test has undergone. Nevertheless, now that we have had some experience of both tests, we feel that each possess certain advantages over the other. For instance, the CHC test is performed and completed on the day of surgery. The CSFT test cannot be started for at least a week after the biopsy. Moreover, the $\mathrm{CHC}$ test requires less skill than does the SCFT test. A full time technician should be able to leam to do the former test after a training period of about two to four weeks. About two to four months is required, however, for even the most skilled technician to learn the intracacies of the CSFT test. For each procedure the most difficult part is learning to dissect and mount the muscle specimen (fascicle or fibre) without damage. Preparing a nearly invisible single skinned muscle cell is, of course, much more difficult than preparing a fascicle of several hundred intact muscle cells one or two centimetres long. For the CHC test all fascicles can be examined simultaneously while for the CSFT test each fibre must be examined sequentially. The latter test is, therefore, much more time consuming than the former. Furthermore, in the CSFT test, moment to moment monitoring of each fibre by the technician is much more onerous than in the $\mathrm{CHC}$ test. For instance, the fibre must be observed frequently through a microscope. Solutions must be added and removed much more frequently and at much more precise intervals than in the CHC test. Technician fatigue is, therefore, a major problem with the CSFT test and a relatively minor problem with the $\mathrm{CHC}$ test.

On the other hand, the CSFT test does possess certain advantages absent from the CHC test. As previously noted, more is learned about the site and nature of the $\mathrm{MH}$ defect in the CSFT test than in the $\mathrm{CHC}$ test. If an experimental error occurs during the latter test rectification may be difficult if insufficient muscle remains, or if so much time has passed that the remaining muscle has become fatigued. Both are quite possible, since this test requires large amounts of muscle and since fatigue, particularly of the MHS muscle, occurs within a few hours. On the contrary, none of these difficulties are encountered during the CSFT test. The amount of muscle (a few cells) needed is so small that more is always available. Furthermore, the storage solution used preserves the muscle for several months. Since sensitivity of the muscle to caffeine slowly but progressively rises as the months pass, it is recommended that ideally the test should be done between four and ten days after removal from the patient to ensure maximum diagnostic accuracy. For tests of intracellular function and of the influence of various agents on these functions such a restriction is not, however, necessary. The total volume of muscle needed for the CSFT test is much less (about $50 \mathrm{mg}$ ) than the CHC test (2.0 grams). This is an important consideration in small children. Finally, it is possible to send muscle for the CSFT test long distances through the mail from hospital to laboratory. Since in the CHC test muscle measurements must begin within a few minutes of excision, long distance transport is impractical.

In conclusion, the caffeine skinned fibre tension test is a valuable complement to the caffeine-halothane contracture test. However, except in exceptional circumstances, for instance in small children, it should be done only as a complement to the CHC test and not in lieu of it.

\section{ACKNOWLEDGEMENTS}

We wish to thank the Malignant Hyperthermia Association of Canada and the Muscular Dystrophy Association of Canada for their financial support of this project.

\section{Glossary of Terms and Abbreviations}

1 Caffeine-halothane-contracture test $=\mathrm{CHC}$ test.

2 Malignant Hyperthermia $=\mathrm{MH}$

3 Halothane-ATP depletion test $=$ H-ATP-D test.

4 Malignant hyperthermia susceptible = MHS.

5 Caffeine skinned fibre tension test $=$ CSFT test.

6 Caffeine specific concentration without halothane $=$ CSC

7 Increase in tension (in grams) of a skeletal muscle fascicle induced by 1 volume per cent halothane $=\mathrm{H}$-Cont .

8 Caffeine specific concentration with halothane $=\mathrm{CSC}-\mathrm{H}$.

9 [Ethylenebis(oxyethylene-nitrolo)] tetraacetic acid = EGTA.

10 Maximum tension increase of a single chem- 
ically skinned fibre induced by caffeine $=$ Sk-Caff-Max.

11 Dose of caffeine required to initiate a tension increase of a single chemically skinned fibre induced by caffeine $=$ Sk-Caff-D.

12 Dose of caffeine required to initiate a tension increase of a single chemically skinned fibre induced by calcium $=$ Sk-Ca-D.

13 First degree relative $=1^{\circ}$.

14 Second degree relatives and all individuals more distantly related to MHS Patients = $2+{ }^{\circ}$.

15 Greater than normal contracture of intact skeletal muscle fascicle in the presence of halothane, caffeine and caffeine plus halothane $=$ HCK .

16 Greater than normal contracture of intact skeletal muscle fascicle in the presence of caffeine and caffeine plus halothane but no contracture in the presence of halothane alone $=\mathrm{CK}$.

17 Normal contracture in the presence of caffeine and caffeine plus halothane and no contracture in the presence of halothane $=$ C.

18 Greater than normal contracture of intact skeletal muscle fascicle in the presence of caffeine plus halothane but normal contracture in the presence of caffeine and no contracture in the presence of halothane $=$ $\mathrm{K}$.

\section{REFERENCES}

1. Kalow, W., Britt, B.A., Terreau, M.E. \& HaIST, C. Metabolic error of muscle metabolism after recovery from malignant hyperthermia. Lancet $i i: 895$ (1970).

2. Britt, B.A., Kalow, W., Gordon, A., HumPHREY, J.G. \& REWCASTLE, N.B. Malignant hyperthermia - an investigation of five patients. Can. Anaesth. Soc. J. 20:431 (1973).

3. Britt, B.A., EndRenyi, L., Kalow, W. \& PETERS, P.L. The adenosine triphosphate (ATP) depletion test: comparison with the caffeine contracture test as a method of diagnosing malignant hyperthermia susceptibility. Can. Anaesth. Soc. J. 23: 624 (1976).

4. Ellis, R.F., Harriman, D.G.F., Currie, S.\& CAIN, P.A. Screening for malignant hyperthermia in susceptible families. In: Second International Symposium on Malignant Hyperthermia (eds. Aldrete, J.A. and Britt, B.A.), Grune \& Stratton, 1978, p. 273.

5. Ellis, F.R., Harriman, D.G.F., Kyei-Mensah, K. \& TYRELL, J.H. Halothane-induced muscle contracture as a cause of hyperpyrexia. Brit. J. Anaesth. 43: 721 (1971).

6. NELSON, T.E. Excitation-contraction coupling: a common etiologic pathway for malignant hyper- thermia susceptible muscle. In: Second International Symposium on Malignant Hyperthermia (eds. Aldrete, J.A. and Britt, B.A.), Grune \& Stratton, 1978 , p. 23.

7. ANDERSON, 1.L. \& Jones, E.W. Dantrolene sodium in porcine $\mathrm{MH}$ : Studies on isolated muscle strips. In: Second International Symposium on Malignant Hyperthermia (eds. Aldrete, J.A. and Britt, B.A.), Grune \& Stratton, 1978, p. 509.

8. ANDERson, l.L. \& Jones, E.W. Porcine malignant hyperthermia: effect of dantrolene sodium on in vitro halothane-induced contraction of susceptible muscle. Anesthesiology 44: 57 (1976).

9. BRITT, B.A. Malignant hyperthermia - an investigation of three patients. Ann. Roy. Coll. Surg. Engl. 48: 73 (1971).

10. BRIrt, B.A. Preanaesthetic diagnosis of malignant hyperthermia. In: Malignant Hyperthermia (ed. Britt, B.A.), International Anesthesiology Clinics, Volume 17 , No. 4, Little Brown and Company, Boston, 1979, p. 119.

11. Ellis, F.R., KeANeY, N.P. \& Harriman, D.G.F. Histopathological and neuropharmacological aspects of malignant hyperpyrexia. Proc. Roy. Soc. Med. 66: 66 (1973).

12. Ellis, F.R. \& Harriman, D.G.F. A new screening test for susceptibility to malignant hyperpyrexia. Brit. J. Anaesth. 45: 638 (1973).

13. BRITt, B.A., ENDRENY1, L., SCOTt, E. \& Frodis, W. Effect of temperature, time and fascicle size on the caffeine contracture test. Can. Anaesth. Soc. J. 27: 1 (1980).

14. Britt, B.A., Endrenyi, L., Frodis, W., ScotT, E. \& Kalow, W. Comparison of effects of several inhalation anaesthetics on caffeineinduced contractures of normal and malignant hyperthermic skeletal muscle. Can. Anaesth. Soc. J. 27: 12 (1980)

15. Denborough, M.A. Personal communication. Canberra, Australia, 1978

16. Nelson, T.E., Bedell, D.M. \& Jones, E.W. Porcine malignant hyperthermia: effects of temperature and extracellular calcium concentration on halothane-induced contracture of susceptible skeletal muscle. Anesthesiology 42: 301 (1975).

17. Harrison, G.G. A pharmacological in vitro model of malignant hyperpyrexia. S. Afr. Med. J. 47: 774 (1973).

18. Harriman, D.G.F. \& Ellis, F.R. Structural and neuropharmacological aspects of malignant hyperpyrexia. J. Pathol. 107: 9 (1972).

19. ORDING, H. Personal communication. Denmark, (1981).

20. Ranklev, P.C. Personal communication. Sweden, (1981)

21. Blanck, T.J.J. Personal communication. Tucson, Arizona, (1981).

22. Wood, D.S. Human skeletal muscle: analysis of $\mathrm{Ca}^{2+}$ regulation in skinned fibers using caffeine. Exper. Neurol. 58: 218 (1978).

23. WoOD, D.S., Mozo, A. \& WILLNer, J.H. Malignant hyperthermia: the relation of sarcoplasmic reticulum dysfunction to the pathogencsis of the discase. Abstract, American Academy of Neurology, (1978).

24. Woon, D.S. Sarcoplasmic reticulum function 
and caffeine sensitivity in human malignant hyperthermia. IVth International Congress on Neuromuscular Diseases, Montreal, Quebec, (1978).

25. WooD, D.S. Personal communication. New York, N.Y., (1981).

26. Fuchs, F. Inhibition of sarcotubular calcium transport by caffeine: species and temperature dependence. Biochem. Biophys. Acta 172: 566 (1969).

27. Frank, G.B. \& Buss, W.C. Caffeine-induced contractures in mammalian skeletal muscle. Arch. Int. Pharmacodyn. 170: 343 (1967).

28. WEBER, A.\& HERZ, R. The relationship between caffeine contracture of intact muscle and the effect of caffeine on reticulum. J. Gen. Physiol. 52: 750 (1968).

29. FeInSteIn, M.B. Inhibition of caffeine rigor and radioacalcium movements by local anesthetics in frog sartorius muscle. J. Gen. Physiol. 47: 151 (1963).

30. Ogawa, Y. Some properties of fragmented frog sarcoplasmic reticulum with particular reference to its response to caffeine. J. Biochem. 67: 667 (1970).

31. Endo, M., Tanaka, M. \& Ogawa, Y. Calcium induced release of calcium from the sarcoplasmic reticulum of skinned skeletal muscle fibres. Nature 228: 34 (1970).

32. BRITT, B.A. Work in progress, (1982).

33. VinCENZI, F.F. \& HiNDS, T.R. Calmodulin and plasma membrane calcium transport. In: Calcium and Cell Function, Volume 1. Academic Press, Inc., 1980, p. 127.

34. KLEE, C.B. Calmodulin: Structure-function relationships. In: Calcium and Cell Function, Volume 1. Academic Press, Inc., 1980, p. 59.

35. WUYTACK, F., DE SCHUTTER, G. \& CASTEELS, $R$. The effect of calmodulin on the active calcium-ion transport and $\left(\mathrm{Ca}^{2+} \mathrm{Mg}^{2+}\right)$-dependent ATPase in microsomal fractions of smooth muscle compared with that in erythrocytes and cardiac muscle. Biochem, J. 190: 827 (1980).

36. Fischer, E.H., Becker, J.U., Blum, H.E., Byers, B., Heizmane, C. Kerrick, G.W. LeHKY, P., Malencik, D.A. \& Pocinwong, S. Concerted regulation of glycogen metabolism and muscle contraction. Hoppe-Seylers Z. Fur Physiol. Chemie. 356: 379 (1975)

37. Thorpe, W. \& SeEman, P. Drug induced con- tracture of muscle. In: International Symposium on Malignant Hyperthermia (eds. Gordon, R.A., Britt, B.A. and Kalow, W.), Charles C. Thomas, Springfield, 1973, p. 152.

38. Putney, J.W. JR. \& Bianchi, C.P. Effect of dantrolene on E-C coupling in skeletal muscle. Fed. Proc. 32: 772 (1973).

39. Okamura, F., Crocker, B.D. \& Denborough, M.S. Site of the muscle cell abnormality in swine susceptible to malignant hyperpyrexia. Br. J. Anaesth. 52: 377 (1980).

40. Thorens, S. \& Endo, M. Calcium-induced calcium release and "depolarization" induced calcium release: their physiological significance. Proc. Japan Acad. 51: 473 (1975).

41. NeLSON, T.E. Unpublished data, (1982).

42. TAKAGl, A. Increased release of calcium from sarcoplasmic reticulum (SR) by halothane in malignant hyperthermia (MHT). Hiroshima J. Anaesthesia 13 (Suppl.): 155 (1977).

43. NaKano, S., Kumazawa, T., Yamauchi, H., Matsumoto, I., Ikezono, E., Yamatoto, $H$. \& Tomimatsu, T. Further studies on a case of malignant hyperthermia determined by clinical symptoms and skinned fiber technique. Hiroshima J. Anaesthesia 15: 173 (1979).

44. HAHN, M.J. \& GodT, R.E. Effects of halothane on tension and calcium release in mechanically skinned porcine skeletal muscle: studies on malignant hyperthermia. Presented at the 2 nd International Symposium on Malignant Hyperthermia, Denver, Colorado, April, 1977.

45. TAKaGl, A., Sugita, H., TOYOKURA, Y. \& ENDO, M. Malignant hyperpyrexia. Effect of halothane on single skinned muscle fibers. Proc. Japan Acad. 52: 603 (1976).

46. NaKano, S., Kumazawa, T., Yamauchi, H., Matsumoto, I., Ikezono, E., Yamamoto, H. \& Tomimatsu, T. A more detailed case study of malignant hyperthermia determined by a clinical course and a skinned fiber technique. Hiroshima J. Anaesthesia 16 (Suppl.): 67 (1980).

47. Takagl, A., Sunohara, N. \& Nonaka, I. Sensitivity of muscle fiber to halothane or caffeine in vitro. Analyses on calcium loaded single skinned fibers. Hiroshima J. Anaesthesia 16 (Suppl.): 187 (1980).

48. KaRPATI, G. Personal communication. Montreal, Quebec, (1981).

\section{RESUME}

Nous avons comparé deux épreuves diagnostiques pour l'hyperthermie maligne (MH) - le test de contracture caféine sur fibres dépouillées. Les deux tests ont montré une relation fortement positive entre eux et avec l'incidence de réactions causées par l'hyperthermie maligne. Le premier test est plus rapide et plus facilement réalisable. Cette dernière épreuve nécessite moins de muscle et permet le storage du spécimen pour des périodes de temps prolongées. 